\title{
Comparative efficiency of ammonium sulfate alone and ammonium sulfate- octanoic acid combined methods in the purification potential of antibodies
}

\author{
Ahsan Naveed ${ }^{1 *}$, Sajjad Ur Rahman ${ }^{1}$, Sabahat Abdullah ${ }^{1}$ and Rabia \\ Naveed $^{2}$ \\ 1. Institute of Microbiology, University of Agriculture, Faisalabad-Pakistan \\ 2. Department of Chemistry and Biochemistry, University of Agriculture, Faisalabad-Pakistan \\ *Corresponding author's email: 2008ag2901@uaf.edu.pk
}

Citation

Ahsan Naveed, Sajjad Ur Rahman, Sabahat Abdullah and Rabia Naveed. Comparative efficiency of ammonium sulfate alone and ammonium sulfate-octanoic acid combined methods in the purification potential of antibodies. Pure and Applied Biology. Vol. 8, Issue 2, pp1698-1706. http://dx.doi.org/10.19045/bspab.2019.80113

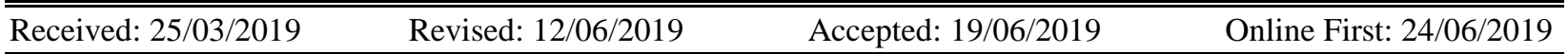

\section{Abstract}

The use of antibodies in the biopharmaceuticals has been increased from therapeutic to prevention through vaccination. However, the purification processes adopted by the industries make them expensive to use. Ammonium sulfate precipitation is an old and easy way to purify the antibodies from the serum and egg yolks. The purity is somewhat compromised with ammonium sulfate precipitation, therefore, a combination of chromatographic techniques is adopted. Presently, ammonium sulfate alone and in a combination with Octanoic acid was used for the purification of antibodies from caprine serum and the egg yolk. The results of purified antibodies in terms of their yield and purity were compared through statistical analysis. The overall study results indicated a better yield and purity of antibodies from the caprine serum through a combined treatment of ammonium sulfate with Octanoic acid, whereas, ammonium sulfate alone gave a better yield but less pure antibodies from the egg yolk. Ammonium sulfate-Octanoic acid combined precipitation of caprine serum yielded $6.67 \mathrm{mg} / \mathrm{mL}$ while sole ammonium sulfate yielded $4.49 \mathrm{mg} / \mathrm{mL}$ purified antibodies. In case of IgY Ammonium sulfate-Octanoic acid combined precipitation of yielded only $8.90 \mathrm{mg} / \mathrm{mL}$ while sole ammonium sulfate yielded $13.80 \mathrm{mg} / \mathrm{mL}$ purified antibodies. A combination of ammonium sulfate and Octanoic acid is a good choice for high yield and purity of antibodies from serum. The purity of antibodies from the egg yolk was enhanced through ammonium sulfate in combination with Octanoic acid but the overall yield was poor.

Keywords: Antibodies; Ammonium sulfate; Octanoic acid; Precipitation

\section{Introduction}

Antibodies are the immunoglobulins secreted by the immune cells in response to invading pathogens. The specific function of antibodies is to opsonize the pathogens to facilitate their engulfment by the phagocytic cells of the immune system [1]. Presently, the demand for antibodies has been increased because of their biopharmaceutical uses and applications in certain therapeutic strategies 
[2]. The applications of immunoglobulin $G$ (IgG) in the field of biomedical science are increasing for therapeutic and prevention through drug and vaccine preparations [3]. The commercially available IgG is purified through chromatographic techniques, although it increases the purity of the antibodies but at the same time makes them more expensive and limit their use [4]. Another important immunoglobulin employed in the biomedical field is egg yolk immunoglobulin $\mathrm{Y}(\operatorname{IgY})$ from the hens [5]. The IgY has more advantages over the mammalian IgG because of its phylogenetic distance. The IgY does not react with rheumatoid factor, fragment crystallizable $(\mathrm{Fc})$ receptors of the bacteria and mammalian complement system [6]. IgY is able to induce more strong immune response compared to $\mathrm{IgG}$ as $\mathrm{Ig} \mathrm{Y}$ can recognize more epitopes of highly conserved mammalian proteins. The IgY are also employed in the treatment and prevention of various animal disease as in mastitis, bovine viral diarrhea [7]. Recently, a new concept of $\operatorname{IgY}$ based vaccines preparations has been introduced because of their potential therapeutics. The limited use of IgY is attributed to the time consuming and difficult practices of purifying antibodies. Purification of antibodies from the serum and egg yolk is carried out through various procedure including chromatographic procedures, soluble phase water dilutions, filtrations and temperature and $\mathrm{pH}$ changes [8]. Ammonium sulfate precipitation is an efficacious and easy way to purify antibodies. Antibody purification through ammonium sulfate precipitation involves a high concentration of charged ammonium sulfate ion that competes with the protein particles to bind the water molecules [9]. The water molecules from the proteins are removed by the ammonium sulfate salt resulting precipitation of the antibodies. A variable concentration from $40 \%$ to $50 \%$ of ammonium sulfate is used for this precipitation. It is not a single step, however, the precipitation of protein through ammonium sulfate may yield impure antibodies. Further steps are combined with ammonium sulfate precipitation for complete purification and high yield [10]. Caprylic acid a short chain fatty acid that may precipitate the serum proteins other than IgG. This purification process gives a high yield of proteins, the drawback of caprylic acid is impurities that can be reduced through combined methods [11]. The present study was performed to evaluate the potential of ammonium sulfate and octanoic acid precipitation. Ammonium sulfate alone and in combination with octanoic acid was employed for the precipitation of antibodies from the caprine serum and egg yolk.

\section{Materials and methods}

Ammonium sulfate precipitation method has been used since long for the precipitation of antibodies. Presently, a comparative study was performed for antibody separation and purifications form the serum and egg yolks.

\section{Serum separation from the goats}

A $10 \mathrm{~mL}$ of blood was aseptically collected from the teddy goat. The blood was centrifuged at 10,000 rpm for 5 min to obtain fresh caprine serum. The serum was stored at $-20{ }^{\circ} \mathrm{C}$ for further studies.

\section{Separation of serum antibodies through ammonium sulfate precipitation}

Acetate buffer was prepared using Sodium acetate and Glacial acetic acid (SIGMAALDRICH,

Acetic acid glacial, $\geq 99.85 \%$ ) and the $\mathrm{pH}$ was adjusted at 4.5 . The serum was diluted with an acetate buffer at 1: 3 ratios.

The serum was added with $0.24 \mathrm{~g} / \mathrm{mL}$ of ammonium sulfate and incubated for half an hour at $25{ }^{\circ} \mathrm{C}$ with continuous stirring. Then the samples were centrifuged at $10,000 \mathrm{Xg}$ under $4{ }^{\circ} \mathrm{C}$ for $12 \mathrm{~min}$ and the supernatant was discarded. The pellets were added with a small volume of $2 \mathrm{M}$ ammonium sulfate solution and re-incubated for half an hour at 
$25{ }^{\circ} \mathrm{C}$ following the centrifugation at 10,000 $\mathrm{Xg}$ under $4{ }^{\circ} \mathrm{C}$ for 12 mins. Lastly, the supernatant was discarded and the pellet was re-suspended in a small volume of phosphate buffer saline (PBS) [12].

The serum was dialyzed against 70 volumes of PBS for a period of $48 \mathrm{hrs}$, the completion of dialyzation was confirmed using $0.1 \mathrm{M}$ silver nitrate (Silver nitrate crystal. extra pure, Merck). The dialyzed serum was placed in a water bath at $60{ }^{\circ} \mathrm{C}$ for 30 mins and then subjected to final centrifugation at $2800 \mathrm{Xg}$ for 20 mins. The pellet was dissolved in 0.5 $\mathrm{mL}$ of PBS and proteins were quantified through Nanodrop (Thermo Scientific, NanoDrop 8000) quantification technique.

Separation of serum antibodies through ammonium sulfate-octanoic acid precipitation

The serum was diluted through the previously described method and a $25 \mu \mathrm{L} / \mathrm{mL}$ concentration of Octanoic acid (OA) was dropwise added to the diluted serum with continuous stirring for a period of 30 mins. After then the serum was centrifuged for 20 mins at $11200 \mathrm{Xg}$ and the supernatant was added with one part of PBS. The $\mathrm{pH}$ was adjusted to 7.4 and serum was cold to $4{ }^{\circ} \mathrm{C}$, in the very next step $1 \mathrm{~mL}$ of $40 \%$ ammonium sulfate (SIGMA-ALDRICH, $\geq 99.0 \%$ ) was added dropwise to the serum. The fractionated serum proceeded to centrifugation at $2800 \mathrm{Xg}$ for a period of $20 \mathrm{~min}$ and supernatant was discarded. The pellet was re-dissolved in a small volume of PBS and dialyzed with 70 volumes of PBS for $48 \mathrm{hrs}$.

\section{Collection of egg yolks}

Fresh table eggs from layer (Novogen white) were collected. The eggs were cleaned with a cotton swab dipped in $70 \%$ ethanol solution. The egg yolks were aseptically separated from the egg whites and placed in sterilized falcon tubes for further research studies. The egg yolk was separated from the egg white and washed twice with distilled water at $4{ }^{\circ} \mathrm{C}$ to remove After proper washing the yolk was separated from the membrane and proceeded for further studies.

Pre-treatment of egg yolk and separation of antibodies

A $2 \mathrm{~mL}$ of egg yolk was diluted 9 folds with distilled water at $4{ }^{\circ} \mathrm{C}$ and $\mathrm{pH}$ was adjusted to 5.0 with the addition of IN $\mathrm{HCl}$. The $\mathrm{pH}$ was readjusted at 4.0 after the addition of $0.01 \%$ charcoal. The diluted egg yolks were subjected to overnight freezing at $-20^{\circ} \mathrm{C}$. The next day, the diluted sample was thawed at 4 ${ }^{\circ} \mathrm{C}$ and centrifuged for 10 mins at $8000 \mathrm{Xg}$ under $4{ }^{\circ} \mathrm{C}$. The supernatant was used for antibody separation [13].

The egg yolk antibodies were separated through both of the previously described methods for serum antibody separation.

Purity Assessment of the antibodies

The purity of caprine IgG and egg yolk IgY was assessed through Sodium Dodecyl Sulphate-Poly Acrylamide Gel Electrophoresis (SDS-PAGE). A discontinuous buffer system was applied for the experiment [14].

\section{Results}

\section{Precipitation of caprine serum antibodies} (IgG)

The serum containing the highest percentage of antibody titer proceeded to combined Octanoic acid-ammonium sulfate and sole ammonium sulfate precipitation separately. The initial treatment resulted in precipitation of the lipids and non-IgG proteins within half an hour of incubation. The centrifugation of the Eppendorf tubes resulted in pellet formation as shown in (Figure 1a). The supernatant was collected, the secondary treatment resulted in the formation of a clear white pellet of IgG proteins as shown in (Figure 1b). 

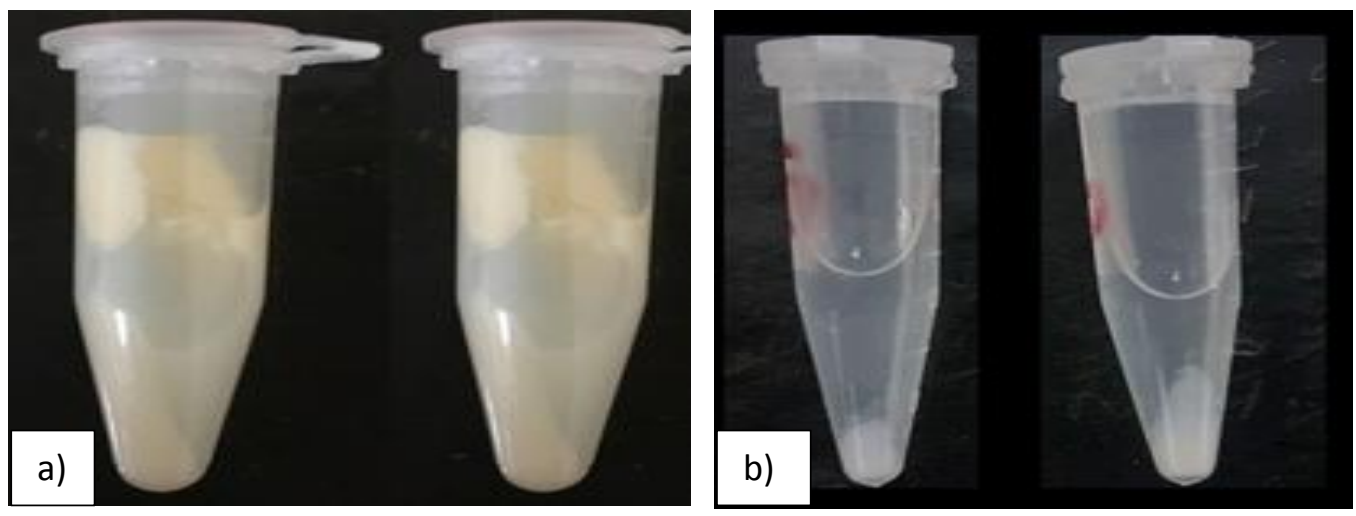

Figure 1(a). Eppendorf tube showing dissolved lipid contents of goat serum pelleted after Octanoic acid treatment Figure 1(b). The pellets of proteins sediment after ammonium sulfate precipitation step

Quantification of caprine serum antibodies (IgG)

Five samples were measured for total protein contents of ( $\operatorname{IgG})$ through Nanodrop spectrophotometer, $\quad(\mathrm{IgG}) \quad$ protein concentration was above $6 \mathrm{mg} / \mathrm{mL}$ as shown in (Figure 2). A maximum $\mathrm{IgG}$ protein concentration $7.42 \mathrm{mg} / \mathrm{mL}$ while a minimum of $6.04 \mathrm{mg} / \mathrm{mL}$ concentration was detected in the selected samples. The pooled protein concentration of the $\mathrm{IgG}$ contents in the Ammonium sulfate-Octanoic acid (AS-OA) precipitated samples were recorded to 6.67 $\mathrm{mg} / \mathrm{mL}$. The comparative IgG contents in the ammonium sulfate precipitated caprine serum was very low. The selected five samples showed a maximum of $5.01 \mathrm{mg} / \mathrm{mL}$ protein contents through Nanodrop quantification. Most of the $\mathrm{IgG}$ contents in AS precipitated serum were below $5 \mathrm{mg} / \mathrm{mL}$ as presented in (Figure 2). Pooled protein contents of $4.49 \mathrm{mg} / \mathrm{mL}$ were recorded from selected serum samples. Overall $\mathrm{IgG}$ contents of serum proteins precipitated with Ammonium sulfate-Octanoic acid combined treatment was higher than sole ammonium sulfate precipitation.

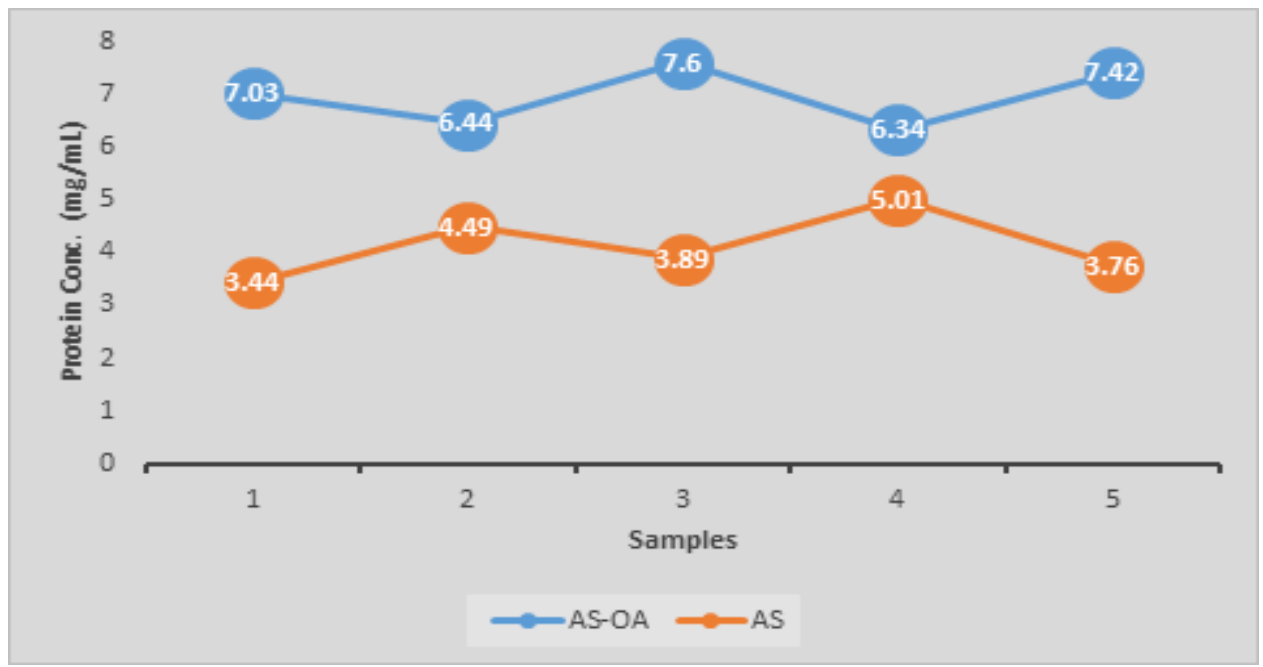

Figure 2. Comparative Caprine Serum Protein (IgG) Concentrations obtained through sole Ammonium sulfate and Ammonium sulfate-Octanoic acid precipitation 
The purity of IgG antibodies

The caprine immunoglobulin $\mathrm{G}$ was assessed through SDS-PAGE, the bands of $150 \mathrm{kDa}$ in (Figure 3) are indicating the presence of $\mathrm{IgG}$ in the serum. Band density of ammonium sulfate-octanoic acid combined treatment is indicating more IgG contents in the lane ASOA while the lane AS is indicating fewer IgG contents after precipitation with ammonium sulfate alone.

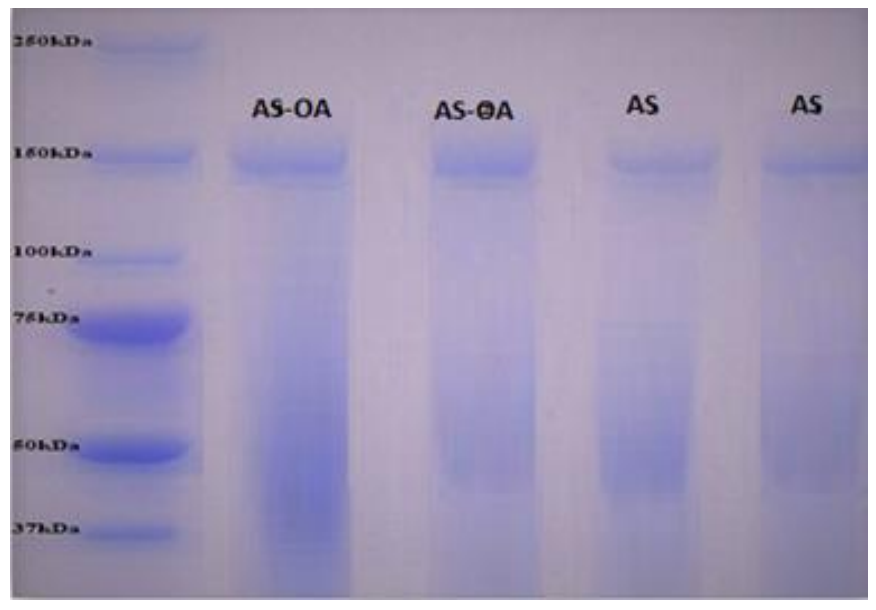

Figure 3. SDS-PAGE gel indicating bands of caprine IgG of $150 \mathrm{kDa}$ after staining with Coomassie blue stain. The lane AS-OA is indicating ammonium sulfate-octanoic acid treatment while lane $\mathrm{AS}$ is indicating ammonium sulfate precipitated IgG contents

Precipitation of Egg yolk antibodies (IgY)

The charcoal treated egg yolk upon centrifugation formed a pellet at the bottom of the Eppendorf tube. In (Figure 4a) depicts precipitation of lipids and non-IgY proteins present in the egg yolk after primary treatment of diluted egg yolk with ammonium sulfate that resulted in yellow

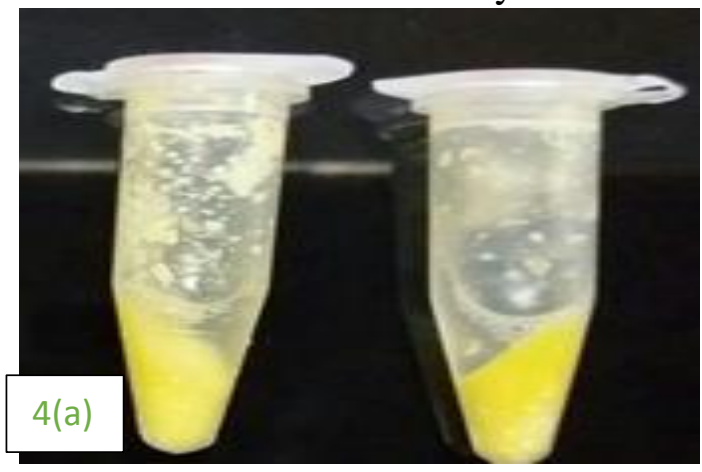

pellet formation upon centrifugation. More lipid contents were observed in primary treatment. The secondary treatment with $2 \mathrm{M}$ ammonium sulfate resulted in precipitation of IgY proteins that resulted in the formation of the clear white pellet as in (Figure 4b)). The supernatant was discarded and the pallets were dialyzed overnight against PBS.

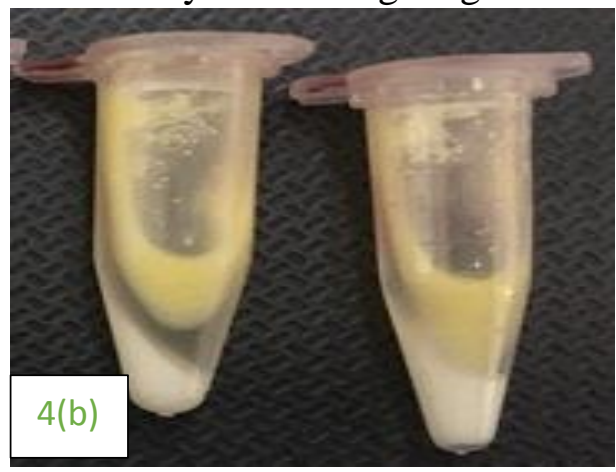

Figure 4(a) Eppendorf tube showing dissolved lipids after treatment with $40 \%$ Ammonium sulfate, Figure 4(b) the secondary treatment with $2 \mathrm{M}$ ammonium sulfate precipitation and centrifugation at $10000 \mathrm{Xg}$ resulted in sedimentation of IgY proteins in the form of a clear white pellet 
Quantification analysis of egg yolk antibodies (IgY)

The $\operatorname{IgY}$ protein concentrations obtained from the sole ammonium sulfate precipitated egg yolks were more than $13 \mathrm{mg} / \mathrm{mL}$ in most of the samples processed. From the selected five samples a maximum of $14.14 \mathrm{mg} / \mathrm{mL}$ protein concentration was obtained while the minimum protein concentration obtained was $13.04 \mathrm{mg} / \mathrm{mL}$ as represented in (Figure 5). The pooled protein concentration of ammonium sulfate precipitated egg yolks was $13.80 \mathrm{mg} / \mathrm{mL}$.
A variable protein concentration from 8.64 $\mathrm{mg} / \mathrm{mL}$ to $9.33 \mathrm{mg} / \mathrm{mL}$ was recorded from the selected five egg yolk samples precipitated with AS-OA. However, most of the concentrations were less than $9 \mathrm{mg} / \mathrm{mL}$, a maximum of $9.33 \mathrm{mg} / \mathrm{mL}$ protein concentration was observed as indicated in Figure 5. Pooled protein concentration in ASOA precipitation was $8.90 \mathrm{mg} / \mathrm{mL}$. The $\mathrm{IgY}$ contents of the egg yolk precipitated with sole ammonium sulfate were comparatively higher than IgY of egg yolk precipitated with AS-OA combined treatment.

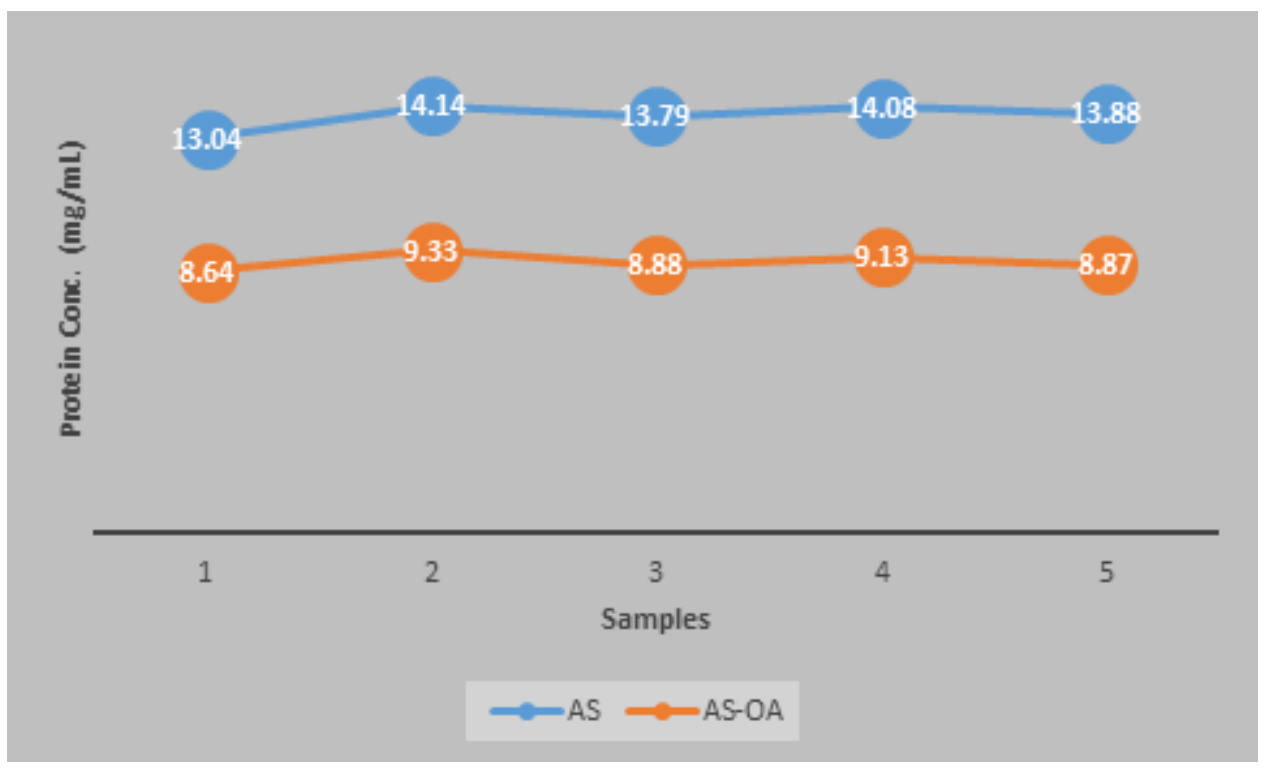

Figure 5. Comparative Egg Yolk Protein (IgY) Concentrations obtained through sole Ammonium sulfate and Ammonium sulfate-Octanoic acid precipitation

\section{Purity Assessment of IgY}

In (Figure 6) is indicating $\operatorname{Ig} Y$ contents assessed for their purity through SDS-PAGE. The IgY of $180 \mathrm{kDa}$ were detected, lane YAS is indicating ammonium sulfate precipitated IgY contents. The band density is indicating more $\mathrm{IgY}$ contents in lane Y-AS while purity was bit compromised. The lane Y-AS-OA is indicating IgY contents obtained after ammonium sulfate-octanoic acid combined treatment. The band on Y-AS$\mathrm{OA}$ are indicating IgY contents were pure but decreased in concentration. 


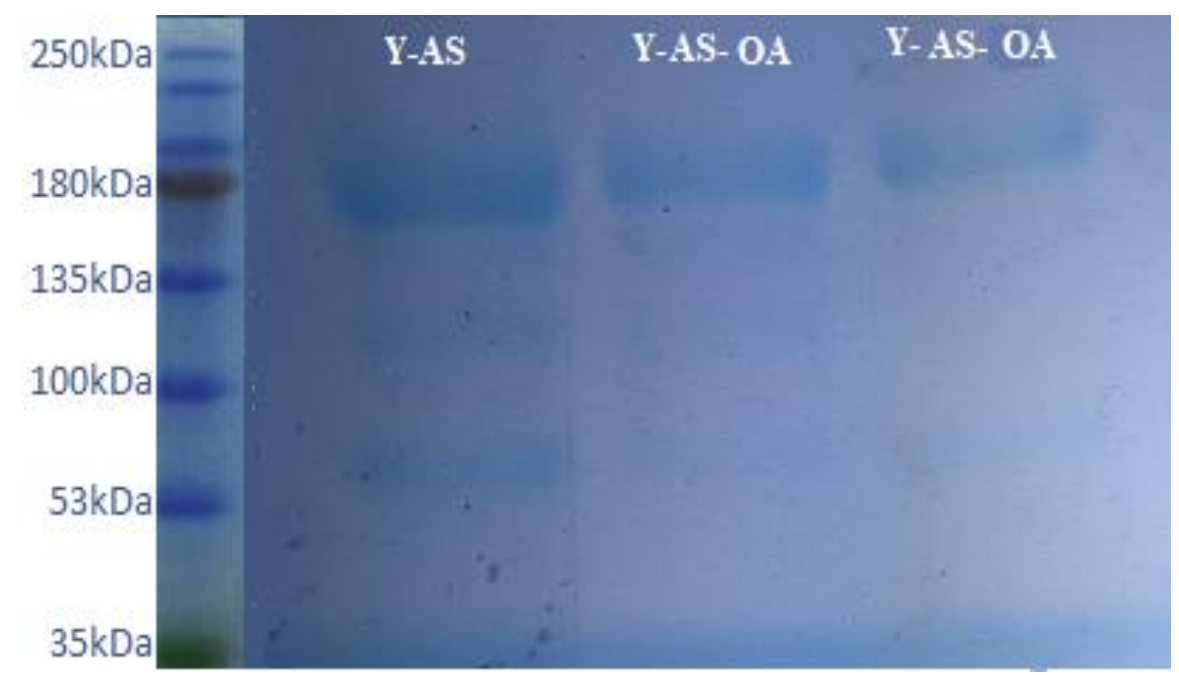

Figure 6. SDS-PAGE gel indicating bands of egg yolk antibodies IgY of $180 \mathrm{kDa}$ after staining with Coomassie blue stain. The lane Y-AS-OA is indicating ammonium sulfateoctanoic acid treatment while lane $\mathrm{Y}$-AS is indicating ammonium sulfate precipitated IgY contents

\section{Discussion}

The present research was performed to evaluate comparative precipitation potential of the Octanoic acid and ammonium sulfate to purify antibodies from the serum and egg yolk. The caprine serum was used for the purification of $\operatorname{IgG}$ proteins through a combined ammonium sulfate-octanoic acid precipitation (AS-OA) and sole ammonium sulfate precipitation. A similar method was employed for the precipitation of $\operatorname{IgY}$ from the egg yolk.

AS-OA method is an efficient way to purify antibodies from serum. The method is superior to affinity chromatography and HPLC in terms of yield of antibodies [15]. AS-OA method was used for the purification of serum antibodies and results in terms of high yield and purity of antibodies were similar to the research conducted by Perosa $e t$ al., 1990 [16]. A protein concentration of $7.60 \mathrm{mg} / \mathrm{ml}$ was obtained through AS-OA precipitation of the caprine serum. The results of IgG purification were in agreement with the two-step procedure adopted by and Parkinson in 1987 for purification of $\operatorname{IgG}$ through caprylic acid-ammonium sulfate method. Presently, the lipids and non $\operatorname{IgG}$ fragments were removed by OA while $\mathrm{IgG}$ was salted out by AS precipitation [12]. Stec et al., 2004 used ammonium sulfate precipitation method with HPLC for the isolation of $\mathrm{IgG}$ from bovine serum [17]. The results of the present study are correlated in terms of yield and purity of the antibodies except for the minor impurities. However, the sole ammonium sulfate precipitation of caprine serum yielded fewer IgG contents compared to AS-OA precipitation.

The antibodies were separated from the egg yolk of layer birds with ammonium sulfate precipitation alone and a combined AS-OA treatment was given to the diluted egg yolks for IgY precipitation. The results of antibody separation were similar to the results of Ko and Ahn, 2007 where they demonstrated ammonium sulfate precipitation method is superior to cation exchange chromatography in terms of yield and purity for antibodies separation [18]. Ammonium sulfate precipitation alone gives better yield and purity as compared to Octanoic acid for separation of IgY from the egg yolk [19]. The results of the present study were correlated 
with (Barati et al., 2018) where they used the freeze-thaw method with sodium chloride precipitation method for the purification of IgY from the egg yolk [20]. IgY have a protective effect on the animal models and can be easily used for experimentation. Presently, a maximum of $14.14 \mathrm{mg} / \mathrm{ml} \mathrm{IgY}$ protein contents was measured from sole ammonium sulfate precipitated egg yolks.

\section{Conclusion}

The overall study evidenced a combined ammonium sulfate-octanoic acid precipitation was superior to the sole ammonium sulfate precipitation from the serum, however, the reverse was true for the purification of antibodies from the egg yolk. The combined ammonium sulfate-octanoic acid treatment enhanced the purity of the antibodies from both of the sources, however, the yield of antibodies was compromised in when precipitated from egg yolk.

\section{Authors' contributions}

Conceived and designed the experiments: A Naveed \& SU Rahman, Performed the experiments: A Naveed \& S Abdullah, Analyzed the data: R Naveed \& SU Rahman, Contributed materials/ analysis/ tools: R Naveed, Wrote the paper: A Naveed \& R Naveed.

\section{Acknowledgments}

We would like to acknowledge the United States-Pakistan Center for the advanced studies for their financial support through scholarship during the research.

\section{References}

1. Buchacher A \& Iberer G (2006). Purification of intravenous immunoglobulin $\mathrm{G}$ from human plasma aspects of yield and virus safety. Biotechnol J 1: 148-163.

2. Stiehm ER, Keller MA \& Vyas GN (2008). Preparation and use of therapeutic antibodies primarily of human origin. Biologic 36: 363-374.

3. Lemieux R, Bazin R \& Néron S (2005). Therapeutic

intravenous immunoglobulins. Mol Immunol 42: 839-848.

4. Catarina CR, Catarina MSSN, Maria VQ, João APC \& Mara GF (2018). Separation of immunoglobulin G using aqueous biphasic systems composed of cholinium-based ionic liquids and poly (propylene glycol). J Chem Technol Biotechnol 93: 1931-1939.

5. Hamal KR., Burgess SC, Pevzner IY \& Erf GF (2006). Maternal antibody transfers from dams to their egg yolks, egg whites, and chicks in meat lines of chickens. Poult Sci 85: 1364-1372.

6. Edzard S, Ingke B, Kerstin G, Henning S, Simon B \& Dion P (2012). Avian IgY antibodies and their recombinant equivalents in research, diagnostics and therapy. Biologicals 40: 313-322.

7. Wang LH, Li XY, Jin LJ, You JS, Zhou Y, Li SY \& Xu YP (2011). Characterization of chicken egg yolk immunoglobulins (IgYs) specific for the most prevalent capsular serotypes of mastitis-causing Staphylococcus aureus. Vet Micro 149: 415-421.

8. Tan SH, Mohamedalia A, Kapur A, Lukjanenko L \& Baker MS (2012). A novel, cost-effective and efficient chicken egg IgY purification procedure. J Immunol Methods 380: 73-76.

9. Tong C, Geng F, He Z, Cai Z, and Ma M (2015) A simple method for isolating chicken egg yolk immunoglobulin using effective delipidation solution and ammonium sulfate. Poultry Sci 94: 104110.

10. Simsiriwong $\mathrm{P}$, Eursakun $\mathrm{S} \quad \&$ Ratanabanangkoon K (2012) A study on the use of caprylic acid and ammonium sulfate in combination for the fractionation of equine anti-venom $\mathrm{F}(\mathrm{ab})$ 2. Biologic 40: 338-344.

11. Shawki A, El-Baky NA, Ahmed M, Linjawi MH, AlJaddawi AA \& Redwan EM (2017). Simple Protocol for 
immunoglobulin G Purification from Camel "Camelus dromedarius" Serum. Open Life Sci 12: 143-155.

12. McKinney MM \& Parkinson A (1987) A simple, non-chromatographic procedure to purify immunoglobulins from serum and ascites fluid. J Immunol Methods 96(2): 271-278.

13. Ferella A, Bellido D \& Chacana P, et al (2012). Chiken egg yolk antibodies against bovine respiratory syncytial virus neutralizes the virus in vivo. Procedia in Vaccinol 6: 33-38.

14. Hensel U, Wellensiek HJ \& Bhakdi S (1985). Sodium Dodecyl SulfatePolyacrylamide Gel Electrophoresis Immunoblotting as a Serological Tool in the Diagnosis of Syphilitic Infections. $J$ Clin Microbiol 21: 82-87.

15. Temponi M, Federico TK \& Perosa PF, et al. (1989) Purification of Murine IgG Monoclonal Antibodies by Precipitation with Octanoic acid: Comparison with Other Methods of Purification. Hybridoma 8: 85-95.

16. Perosa F, Carbone R \& Ferrone $\mathrm{S}$ et al. (1990). Purification of human immunoglobuhns by sequential precipitation with Octanoic acid and ammonium sulphate. $J$ Immunol Methods 128: 9-16.

17. Stec J, Bicka L \& Kuzmak J (2004). Isolation and Purification of Polyclonal IgG Antibodies from Bovine Serum by High-Performance Liquid Chromatography. Bull Vet Inst Pulawy 48: 321-327.

18. Ko KY \& Ahn DU (2007) Preparation of Immunoglobulin $Y$ from Egg Yolk Using Ammonium Sulfate Precipitation and Ion Exchange Chromatography. Poultry Sci 86: 400-407.

19. Svendsen L, Crowley A \& Ostergaard LH (1995). Development and comparison of purification strategies for chicken antibodies from egg yolk. $L a b$ Anim Sci 45: 89-93.

20. Barati B, Ebrahimi F \& Nazarian S (2018). Production of Chicken Egg Yolk Antibody (IgY) Against Recombinant Cholera Toxin B Subunit and Evaluation of Its Prophylaxis Potency in Mice. Iran J Immunol 15: 47-58. 